\title{
PENILAIAN PROPERTI UNTUK MENENTUKAN KEWAJARAN NILAI TRANSAKSI PENGALIHAN HAK ATAS TANAH DAN/ATAU BANGUNAN DI KPP PRATAMA KISARAN
}

\author{
Swedio Frans Tedy ${ }^{1)}$; Heni Sulastri ${ }^{2}$; \\ 1) swediof@gmail.com, Politeknik Keuangan Negara STAN \\ 2) heni.sulastri@pknstan.ac.id, Politeknik Keuangan Negara STAN* \\ *email korespondensi
}

\begin{abstract}
The purpose of this study is to review the property appraisal process in order to determine the fairness of the transaction value of the transfer of land and/or building rights, which in this study will focus on the Kantor Pelayanan Pajak (KPP) Pratama Kisaran. A review is also carried out to identify the obstacles found in the assessment process and to match the suitability of the applicable regulations and their application in practice in the field. The research was conducted by direct observation in the field as well as literature study of standard operating procedures, applicable regulations, and assessment reports. The results of the study indicate that the implementation of the assessment that has been carried out is generally appropriate but there are still obstacles in the property appraisal process in order to determine the fairness of the transaction value of the transfer of land and/or building rights. Therefore, this research can be used as consideration for evaluating so that the assessment process is more effective, efficient and on target.
\end{abstract}

Keywords : Appraisal, transfer of rights on land and/or buildings, fairness of transactions.

\begin{abstract}
Abstrak
Tujuan penelitian ini adalah untuk meninjau proses penilaian properti dalam rangka menentukan kewajaran nilai transaksi pengalihan hak atas tanah dan/atau bangunan, dimana dalam studi ini akan berfokus di Kantor Pelayanan Pajak (KPP) Pratama Kisaran. Peninjauan juga dilakukan untuk mengidentifikasi kendala yang ditemukan dalam proses penilaian serta mencocokkan kesesuaian peraturan yang berlaku dan penerapannya dalam praktek di lapangan. Penelitian dilakukan dengan cara observasi langsung di lapangan serta studi literatur standar operasional prosedur, peraturan-peraturan yang berlaku, serta laporan penilaian. Hasil penelitian menunjukkan bahwa pelaksanaan penilaian yang telah dilakukan secara umum telah sesuai tetapi masih terdapat kendala dalam proses penilaian properti dalam rangka menentukan kewajaran nilai transaksi pengalihan hak atas tanah dan/atau bangunan. Karena itu penelitian ini dapat dijadikan sebagai bahan pertimbangan untuk melakukan evaluasi agar proses penilaian lebih efektif, efisien dan tepat sasaran.
\end{abstract}

Kata Kunci : Penilaian, Pengalihan Hak, Kewajaran Transaksi.

\section{PENDAHULUAN}

Penghasilan dari pengalihan hak atas tanah dan/atau bangunan adalah penghasilan yang diterima atau diperoleh pihak yang mengalihkan hak atas tanah dan/atau bangunan melalui penjualan, tukar-menukar, pelepasan hak, penyerahan hak, lelang, hibah, waris, atau cara lain yang disepakati antara para pihak. Dengan demikian, atas segala kegiatan yang menyebabkan berpindahnya hak atas tanah dan/atau bangunan dari satu pihak ke pihak lain akan dikenakan pajak berdasarkan ketentuan dalam Pasal 4 ayat 2 Undang-Undang Nomor 7 Tahun 1983 tentang Pajak Penghasilan sebagaimana telah beberapa kali diubah terakhir dengan UndangUndang Nomor 36 Tahun 2008 (UU PPh). Wajib pajak yang telah memenuhi kewajiban penyetoran pajak penghasilannya harus menyampaikan permohonan penelitian sebagai bukti pemenuhan kewajiban penyetoran pajak penghasilan ke Kantor Pelayanan Pajak. Sesuai dengan PER-18/PJ/2017 yang telah diperbaharui dengan PER-21/PJ/2019, penelitian bukti pemenuhan kewajiban tersebut terbagi ke dalam dua bagian, yaitu penelitian formal dan penelitian material.

Penelitian formal berfungsi untuk mengecek kelengkapan berkas wajib pajak dan memastikan kesesuaian data yang tertera dalam surat permohonan, sedangkan penelitian material berfungsi untuk memastikan kebenaran jumlah pajak yang terutang atas pengalihan hak atas tanah dan/atau bangunan. Dalam penelitian material, salah satu hal yang diperlukan untuk memastikan kebenaran jumlah pajak yang terutang adalah dengan menentukan kewajaran 
nilai pengalihan hak atas tanah dan/atau bangunan dengan nilai pasar berdasarkan pendekatan penilaian (appraisal). Penilaian tujuan perpajakan digunakan atas transaksi atau data yang memerlukan penilaian, salah satunya untuk transaksi yang diduga ada indikasi ketidakwajaran penghasilan dari transaksi pengalihan harta atas tanah dan/atau bangunan. Transaksi yang diindikasikan tidak wajar, akan berpotensi menimbulkan kekurangan pembayaran pajak penghasilan final Pasal 4 Ayat (2) atas pengalihan hak atas tanah dan/atau bangunan wajib pajak setelah dilakukan penilaian dengan merujuk kepada harga pasar. Namun, penilaian tersebut masih memiliki kendala diberbagai daerah di Indonesia yang menjadi wilayah kerja kantor pelayanan pajak.

Berdasarkan uraian di atas, penelitian berupa tinjauan penilaian properti dalam rangka menentukan kewajaran nilai transaksi pengalihan hak atas tanah dan/atau bangunan di KPP Pratama Kisaran. Penelitian bertujuan melihat pelaksanaan penilaian properti dalam rangka menentukan kewajaran nilai transaksi pengalihan hak atas tanah dan/atau bangunan di KPP Pratama Kisaran. Selain itu, penulis juga ingin mengetahui tantangan dan hambatan yang dihadapi penilai pajak di KPP Pratama Kisaran dalam melakukan penilaian properti dalam rangka menentukan kewajaran nilai transaksi pengalihan hak atas tanah dan/atau bangunan.

Tujuan yang ingin dicapai oleh penulis dalam penelitian ini adalah : (a). Mengetahui pelaksanaan penilaian properti dalam rangka menentukan kewajaran nilai transaksi pengalihan hak atas tanah dan/atau bangunan di KPP Pratama Kisaran. (b). Mengetahui contoh penilaian properti dalam rangka menentukan kewajaran nilai transaksi pengalihan hak atas tanah dan/atau bangunan di KPP Pratama Kisaran. (c). Mengetahui tantangan dan hambatan yang dihadapi penilai pajak di KPP Pratama Kisaran dalam melakukan penilaian properti dalam rangka menentukan kewajaran nilai transaksi pengalihan hak atas tanah dan/atau bangunan.

\section{KAJIAN PUSTAKA}

Menurut sistem Hukum Perdata, Subekti (2001) mengemukakan bahwa suatu pengalihan hak terdiri atas dua bagian, yaitu: (1) perjanjian dengan memindahkan hak; maupun (2) pemindahan atau pengalihan hak itu sendiri. Dalam hal ini terkait jual beli benda tidak bergerak. Berdasarkan pernyataan tersebut dapat dikatakan bahwa pengalihan hak atas tanah dan/atau bangunan adalah beralihnya hak milik seseorang kepada orang lain sebagai pihak kedua, dengan proses jual beli, tukar-menukar atau dengan cara lain yang disahkan secara hukum. Objek peralihan tidak berpindah melainkan hak atas kepemilikannya yang berpindah dari seseorang kepada orang lain, hal ini secara legalitas dapat ditandai dengan berpindahnya nama kepemilikan dalam sertifikat.

Peraturan Pemerintah Nomor 34 Tahun 2016 tentang Pajak Penghasilan atas Penghasilan dari Pengalihan Hak atas Tanah dan/atau Bangunan, dan Perjanjian Pengikatan Jual Beli atas Tanah dan/atau Bangunan Beserta Perubahannya, mengatur antara lain Subjek dan Objek Pajak. Pengalihan hak atas tanah dan/atau bangunan yang dilakukan oleh seseorang kepada orang lain akan menghasilkan penghasilan bagi penerimanya dan akan menimbulkan pajak atas penghasilan yang diterima oleh orang tersebut. Penghasilan dari pengalihan hak atas tanah dan/atau bangunan adalah penghasilan yang diterima atau diperoleh pihak yang mengalihkan hak atas tanah dan/atau bangunan melalui penjualan, tukar-menukar, pelepasan hak, penyerahan hak, lelang, hibah, waris, atau cara lain yang disepakati antara para pihak. Atas penghasilan yang diterima atau diperoleh pihak yang berkaitan baik orang pribadi atau badan dari transaksi pengalihan hak atas tanah dan/atau bangunan tersebut beserta penghasilan yang timbul karena adanya perjanjian pengikatan jual beli baik transaksi tersebut sebagai kegiatan usahanya maupun tidak, wajib dikenakan atasnya pajak penghasilan yang harus dibayar ataupun dipungut pada saat dilakukannya transaksi. Pajak penghasilan yang dikenakan atas penghasilan dari transaksi pengalihan hak atas tanah dan/atau bangunan bersifat final. 
Penelitian Formal, dilakukan oleh KPP yang wilayah kerjanya meliputi lokasi tanah dan/atau bangunan. Penelitian formal dilaksanakan berdasarkan permohonan penelitian bukti pemenuhan kewajiban penyetoran PPh yang disampaikan wajib pajak secara manual atau elektronik, dalam hal sistem informasi sudah tersedia. Penelitian formal dilakukan dengan cara: (1) mengecek kelengkapan surat permohonan penelitian bukti pemenuhan kewajiban penyetoran $\mathrm{PPh}$; dan (2) memastikan kesesuaian: identitas wajib pajak dalam bukti pemenuhan kewajiban penyetoran PPh dengan data di DJP dan/atau fotokopi Kartu Tanda Penduduk (KTP) atau paspor; jumlah PPh yang telah disetor oleh wajib pajak dengan PPh yang seharusnya terutang berdasarkan surat pernyataan; dan kode akun pajak, kode jenis setoran, dan jumlah $\mathrm{PPh}$ yang disetor oleh wajib pajak, dengan data penerimaan pajak dalam modul penerimaan negara.Dalam hal permohonan penelitian telah terpenuhi atau sesuai, KPP menerbitkan Surat Keterangan Penelitian Formal Bukti Pemenuhan Kewajiban Penyetoran Pajak Penghasilan paling lama 3 (tiga) hari kerja sejak tanggal permohonan penelitian diterima lengkap sebanyak 3 (tiga) rangkap. Dalam hal permohonan penelitian tidak terpenuhi atau tidak sesuai, KPP mengembalikan permohonan penelitian bukti pemenuhan kewajiban penyetoran PPh kepada wajib pajak dengan menerbitkan Surat Pemberitahuan Permohonan Penelitian Tidak Lengkap dan/atau Tidak Sesuai paling lama 3 (tiga) hari sejak tanggal permohonan penelitian diterima sebanyak 2 (dua) rangkap.

Penelitian Material, dilakukan KPP setelah Surat Keterangan Penelitian Formal Bukti Pemenuhan Kewajiban Penyetoran Pajak Penghasilan diterbitkan. Penelitian material dilakukan dengan cara: (1) memastikan lokasi dan luas tanah dan/atau bangunan yang dicantumkan dalam surat pernyataan wajib pajak telah sesuai dengan keadaan sebenarnya; (2)meneliti kebenaran nilai pengalihan hak atas tanah dan/atau bangunan yang terdapat dalam bukti penjualan/bukti transfer/bukti penerimaan uang, dalam hal pengalihan tanah dan/atau bangunan berupa jual beli yang tidak dipengaruhi hubungan istimewa; dan (3) menentukan kewajaran nilai pengalihan hak atas tanah dan/atau bangunan yang dinyatakan wajib pajak dengan harga pasar berdasarkan pendekatan penilaian (appraisal), dalam hal pengalihan tanah dan/atau bangunan berupa jual beli yang dipengaruhi hubungan istimewa atau melalui tukarmenukar, pelepasan hak, penyerahan hak, hibah, waris, atau cara lain yang disepakati antara para pihak. Dalam hal berdasarkan penelitian disimpulkan bahwa nilai pengalihan hak atas tanah dan/atau bangunan yang dinyatakan wajib pajak tidak sesuai dan mengakibatkan adanya kekurangan penyetoran PPh terutang, KPP menyampaikan permintaan penjelasan secara tertulis kepada wajib pajak.

Proses Penilaian Properti, dilakukan dalam penilaian properti berdasarkan Surat Edaran Direktur Jenderal Pajak Nomor SE-54/PJ/2016 tentang Petunjuk Teknis Penilaian Properti, Penilaian Bisnis, dan Penilaian Aset Tak Berwujud untuk Tujuan Perpajakan sebagai berikut : (1) Identifikasi Masalah, menjadi langkah awal yang dilakukan penilai dalam melakukan penilaian. Sebelum proses penilaian properti sampai pada tahap penghitungan, diperlukan pemahaman bagi penilai untuk mengetahui mengapa perlu dilakukannya penilaian. Dengan begitu penilai perlu melakukan reviu dan identifikasi masalah atas rencana penugasan sebagai berikut: (1a) penentuan tujuan penilaian; (1b) penentuan dasar penilaian; (1c) identifikasi objek penilaian; (1d) tanggal penilaian; (1e) asumsi dan kondisi pembatas; dan (1f) identifikasi status objek penilaian. (2) Pengumpulan dan Pemilihan Data. Setelah identifikasi masalah dilakukan maka tindakan selanjutnya adalah pengumpulan dan pemilihan data. Pengumpulan data dapat dilakukan secara langsung maupun tidak lansung. Pengumpulan data langsung dengan melakukan survei lapangan sedang pengumpulan data tidak langsung dengan mencari data melalui media online. Kegiatan pengumpulan data diuraikan sebagai berikut: (2a) mengidentifikasi jumlah dan jenis data yang diperlukan; (2b) mengidentifikasi sumber data; (2c) mengidentifikasi kebutuhan tenaga kerja; (2d) membuat rencana kerja; dan (2e) 
mengidentifikasi peraturan perundang - undangan yang berlaku dii bidang terkait properti tersebut. (3) Analisis Data. Melakukan analisis pasar dan analisis penggunaan tertinggi dan terbaik untuk menjelaskan gambaran umum industri. (4) Pendekatan Penilaian.Menerapkan pendekatan dan metode penilaian. Terdapat 3 pendekatan dalam penilaian yaitu: (4a) Pendekatan Data Pasar. Pendekatan Pasar menghasilkan indikasi nilai dengan cara membandingkan aset yang dinilai dengan aset yang identik atau sebanding, berdasarkan informasi harga transaksi atau penawaran yang tersedia. (4b) Pendekatan Biaya.Pendekatan Biaya menghasilkan indikasi nilai dengan menggunakan prinsip ekonomi, dengan pemahaman pembeli tidak akan membayar suatu aset lebih daripada biaya untuk memperoleh aset dengan kegunaan yang sama atau setara, pada saat pembelian atau konstruksi. (4c) Pendekatan Pendapatan.Pendekatan Pendapatan menghasilkan indikasi nilai dengan mengubah arus kas di masa yang akan datang ke Nilai kini. (5) Melakukan Rekonsiliasi Nilai, (6) Membuat Kesimpulan Nilai, (7) Membuat Laporan Penilaian.Prosedur Penilaian untuk Tujuan Perpajakan di Kantor Pelayanan Pajak (KPP) Pratama.

Prosedur penilaian untuk tujuan perpajakan di KPP Pratama berdasarkan Surat Edaran Direktur Jenderal Pajak Nomor SE-05/PJ/2020 dalam lingkup pengalihan hak atas tanah dan/atau bangunan adalah sebagai berikut : (1) Berdasarkan permintaan bantuan Penilaian dari Seksi lain di lingkungan KPP: (1a) Kepala KPP menerbitkan Surat Perintah Penilaian; (1b) dalam hal diperlukan, peninjauan lapangan dilakukan oleh tim visit didampingi oleh Tim Penilai/Penilai; dan (1c) Tim Penilai/Penilai melakukan Penilaian, membuat Laporan Penilaian dan menyampaikan kepada Kepala Seksi yang meminta bantuan Penilaian untuk ditindaklanjuti sesuai ketentuan. (2) Berdasarkan permintaan bantuan Penilaian dari KPP lain dalam rangka penelitian material: (2a) Kepala KPP tempat Wajib Pajak terdaftar menyampaikan permintaan bantuan Penilaian kepada Kepala KPP yang wilayah kerjanya meliputi lokasi objek Penilaian; (2b) dalam hal permintaan bantuan Penilaian disetujui, Kepala KPP yang wilayah kerjanya meliputi lokasi objek Penilaian menerbitkan Surat Perintah Penilaian; dan (2c) Tim Penilai/Penilai KPP yang wilayah kerjanya meliputi lokasi objek Penilaian melakukan Penilaian, membuat Laporan Penilaian dan menyampaikan kepada Kepala KPP yang wilayah kerjanya meliputi lokasi objek Penilaian untuk diteruskan kepada Kepala KPP tempat Wajib Pajak terdaftar.

Pedoman Penilaian Properti Dalam Rangka Menentukan Kewajaran Nilai Transaksi Pengalihan Hak atas Tanah dan/atau Bangunan, berdasarkan SE-28/PJ/2020 adalah sebagai berikut:(1) Account Representative (AR) terlebih dahulu menyusun Laporan Analisis Ketidakwajaran Nilai Pengalihan. (2) Laporan Analisis Ketidakwajaran Nilai Pengalihan merupakan Pemicu Penilaian untuk tujuan perpajakan atas kewajaran nilai transaksi pengalihan yang disampaikan oleh Wajib Pajak. (3) Penilaian dilakukan dalam rangka memperoleh nilai transaksi pengalihan yang mendekati nilai pasar wajar.

\section{METODE}

Penelitian ini menggunakan metode kualitatif dengan studi kasus pada penilaian properti dalam rangka menentukan kewajaran nilai transaksi pengalihan hak atas tanah dan/atau bangunan yang ada di KPP Pratama Kisaran. Studi Kasus ini diharapkan dapat menjelaskan terkait pelaksanaan penilaian properti dalam rangka menentukan kewajaran nilai transaksi pengalihan hak atas tanah dan/atau bangunan yang ada di KPP Pratama Kisaran. Untuk mendukung penelitian kualitatif ini dilakukan wawancara kepada pegawai pada KPP Pratama Kisaran yang mempunyai bidang tugas terkait dengan judul penelitian ini, dan mencermati peraturan yang meliputi bidang tugas tersebut. 


\section{HASIL DAN PEMBAHASAN}

Tinjauan pelaksanaan penilaian properti dalam rangka menentukan kewajaran nilai transaksi pengalihan hak atas tanah dan/atau bangunan di KPP Pratama Kisaran. Berdasarkan wawancara dengan penilai pajak, pelaksanaan penilaian properti dalam rangka menentukan kewajaran nilai transaksi pengalihan hak atas tanah dan/atau bangunan di KPP Pratama Kisaran, dilaksanakan untuk melakukan validasi pembayaran atas transaksi pengalihan hak atas tanah dan/atau bangunan yang dilakukan oleh wajib pajak. Validasi pembayaran diajukan oleh wajib pajak dengan menyampaikan permohonan bukti pemenuhan kewajiban penyetoran $\mathrm{PPh}$ atas penghasilan dari pengalihan hak atas tanah dan/atau bangunan. Pelaksanaan penilaian untuk melakukan validasi harus didahului dengan dua tahap penelitian yaitu, penelitian formal dan penelitian material. Penelitian Formal, berdasarkan wawancara kepada penilai pajak, tahap penelitian formal dilakukan di bagian seksi pelayanan. Pelaksana seksi pelayanan melakukan penelitian formal dengan didasari pada Peraturan Dirjen Pajak Nomor PER-18/PJ/2017 yang telah diperbaharui dengan Peraturan Dirjen Pajak Nomor PER-21/PJ/2019.

Berdasarkan wawancara kepada pelaksana seksi pelayanan, pelaksanaan penelitian formal dilakukan oleh KPP yang wilayah kerjanya meliputi lokasi tanah dan/atau bangunan yang menjadi objek validasi. Penelitian formal dilakukan berdasarkan pada permohonan yang disampaikan oleh wajib pajak baik secara langsung maupun melalui media online pada kanal www.pajak.go.id. Namun pada saat pandemi Covid-19, pelayanan penerimaan permohonan wajib pajak harus disampaikan melalui online atau dikirim via pos untuk mencegah penyebaran virus Covid-19. Permohonan yang diajukan wajib pajak diterima pelaksana seksi pelayanan di tempat pelayanan terpadu (TPT) dan di teruskan ke bagian pelaksana back office seksi pelayanan untuk diteliti apabila kelengkapan data telah dipenuhi.

Berdasarkan wawancara dengan pelaksana seksi pelayanan dan observasi penulis, Penelitian formal di KPP Pratama Kisaran telah sesuai dengan PER-18/PJ/2017 yang telah diperbaharui dengan PER-21/PJ/2019. Penelitian formal di KPP Pratama Kisaran dilaksanakan dengan melakukan pengecekan surat permohonan penelitian bukti pemenuhan kewajiban penyetoran PPh yang disampaikan wajib pajak secara lengkap dan memastikan kesesuaian identitas wajib pajak dengan data di DJP dan/atau fotokopi KTP, jumlah PPh yang telah disetor oleh wajib pajak dengan $\mathrm{PPh}$ yang seharusnya terutang dengan menyandingkan dengan data penerimaan pajak pada MPN dan kode akun pajak, kode jenis setoran.

Setelah dilakukan penelitian formal selesai dilakukan tindakan selanjutnya adalah dengan melakukan validasi. Validasi atas hasil penelitian formal dapat berupa diterima atau ditolak. Diterima apabila hasil penelitian formal atas permohonan wajib pajak telah lengkap dan sesuai. Ditolak apabila hasil penelitian formal tidak lengkap dan/atau tidak sesuai. Apabila hasil validasi diterima, KPP Pratama Kisaran melalui pelaksana seksi pelayanan akan menerbitkan Surat Keterangan (SKET) Penelitian Formal Bukti Pemenuhan Kewajiban Penyetoran Pajak Penghasilan sebanyak 3 (tiga) rangkap kepada wajib pajak. Dalam hal hasil validasi penelitian formal ditolak, KPP Pratama melalui pelaksana seksi pelayanan mengembalikan permohonan wajib pajak dengan menerbitkan Surat Pemberitahuan Permohonan Penelitian Tidak Lengkap dan/atau Tidak Sesuai sebanyak 2 (dua) rangkap kepada wajib pajak. Seluruh kegiatan penelitian formal memiliki jangka waktu paling lama 3 (tiga) hari kerja sejak tanggal permohonan penelitian diterima. Tahap selanjutnya, pelaksana seksi pelayanan melakukan rekapitulasi permohonan yang telah divalidasi diterima lengkap setiap 2 minggu sekali disusun per seksi untuk diteruskan ke AR yang menjadi penanggungjawab wajib pajaknya masing masing. Tindak lanjut yang dilakukan AR berupa penelitian material.

Penelitian material merupakan tindak lanjut dari penelitian formal yang telah dilaksanakan oleh seksi pelayanan. Penelitian material dapat dilakukan di KPP tempat wajib pajak terdaftar sesuai Surat Pemberitahuan Tahunan PPh wajib pajak diadministrasikan atau 
kegiatan usaha dilakukan atau yang wilayah kerjanya didasarkan kepada tempat tinggal bagi wajib pajak belum memiliki Nomor Pokok Wajib Pajak. Berdasarkan wawancara dengan AR, pelaksanaan penelitian material di KPP Pratama Kisaran dilakukan sebagai tindak lanjut atas penelitian formal dengan didasarkan atas SKET Penelitian Formal Bukti Pemenuhan Kewajiban Penyetoran Pajak Penghasilan beserta permohonan validasi bukti pemenuhan kewajiban penyetoran pajak atas penghasilan dari pengalihan hak atas tanah dan/atau bangunan wajib pajak yang telah diterbitkan seksi pelayanan. AR yang dapat melakukan penelitian formal adalah AR seksi pengawasan dan konsultasi I/II/III/IV.

SKET dan permohonan validasi bukti pemenuhan kewajiban penyetoran pajak atas penghasilan dari pengalihan hak atas tanah dan/atau bangunan wajib pajak yang telah diterbitkan oleh seksi pelayanan, tidak semuanya dapat dilakukan penelitian material. AR perlu melakukan pemilihan data, atas SKET permohonan validasi bukti pemenuhan kewajiban, dalam rangka penyetoran pajak atas penghasilan dari pengalihan hak atas tanah dan/atau bangunan yang telah terbit. Pemilihan data ini berdasarkan atas kewajaran besarnya pembayaran pajak atau ketidakwajaran. Jika diindikasikan adanya ketidakwajaran besarnya pembayaran maka AR akan meneruskan ke penelitian material. Ketidakwajaran nilai transaksi diindikasikan dengan membandingkan gambaran nilai transaksi secara umum dengan nilai pasar, melalui informasi pada media online maupun offline, seperti olx. Bagi permohonan validasi bukti pemenuhan kewajiban penyetoran pajak atas penghasilan dari pengalihan hak atas tanah dan/atau bangunan wajib pajak yang terdapat indikasi wajar, AR hanya akan menjadikannya sebagai bahan pengawasan. Tahap selanjutnya, AR sebagai petugas peneliti melakukan penelitian material di KPP Pratama Kisaran dengan cara sebagai berikut (1) Memastikan lokasi dan luasan tanah dan/atau bangunan yang tertera pada permohonan validasi yang disampaikan wajib pajak sesuai dengan kondisi yang aktual. (2) Meneliti kebenaran nilai pengalihan hak atas tanah dan/atau bangunan yang terdapat dalam bukti penjualan/bukti penerimaan uang dengan syarat jual beli tidak dipengaruhi dengan adanya hubungan istimewa. (3) AR dapat menentukan kewajaran nilai pengalihan hak atas tanah dan/atau bangunan yang disampaikan oleh wajib pajak dengan harga pasar berdasarkan pendekatan penilaian (appraisal) dengan meminta bantuan kepada penilai pajak di KPP Pratama Kisaran dalam hal memberikan kepastian nilai pasar wajar, walaupun transaksi jual beli terdapat indikasi adanya hubungan istimewa ataupun tidak.

Untuk menentukan kewajaran nilai dengan harga pasar melalui pendekatan penilaian, AR KPP Pratama Kisaran membuat Laporan Analisis Ketidakwajaran yang disampaikan kepada penilai pajak untuk dijadikan pemicu dalam melakukan penilaian untuk tujuan perpajakan. Namun berdasarkan wawancara dengan penilai, tidak semua AR membuat Laporan Analisis Ketidakwajaran untuk menentukan kewajaran nilai transaksi pengalihan hak atas tanah dan/atau bangunan. Pembuatan Laporan Analisis Ketidakwajaran pada pelaksanaannya memperhatikan volume pekerjaan AR dan potensi pembayaran pajak, sehingga diprioritaskan yang memiliki potensi pembayaran ketidakwajarannya besar.

Setelah penelitian material atas ketidakwajaran pembayaran, AR akan menganalisa pembayaran tersebut dengan ada atau tidak adanya hubungan istimewa. Setelah AR menganalisa pembayaran tersebut dari sisi ketidakwajaran maupun dari unsur hubungan istimewa maka dalam hal terdapat potensi kekurangan penyetoran PPh terutang, KPP Pratama Kisaran menyampaikan permintaan penjelasan dalam bentuk tertulis kepada wajib pajak. Dengan begitu berdasarkan observasi penulis, pelaksanaan penelitian material pada KPP Pratama Kisaran telah sesuai dengan PER-18/PJ/2017 sebagaimana telah diperbaharui dengan PER-21/PJ/2019 dan terdapat kegiatan memilah pembayaran yang berpotensi besar ketidakwajarannya pada saat sebelum dilakukan penelitian material. 
Contoh penilaian properti dalam rangka menentukan kewajaran nilai transaksi pengalihan hak atas tanah dan/atau bangunan yang dapat penulis gambarkan adalah penilaian properti atas tanah di wilayah Kabupaten Asahan, berdasarkan data yang diberikan oleh KPP Pratama Kisaran atas LAP-000/WPJ.00/XX.00/2020 (pada penulisan ini semua identitas wajib pajak/dokumen unit kerja oleh penulis disamarkan untuk menjaga kerahasiaannya). Penilaian properti atas tanah termasuk ke dalam golongan Penilaian Properti Kriteria I. Penilaian Properti Kriteria I dinilai menggunakan pendekatan data pasar.

Tabel 1 Data Transaksi Penawaran Objek Pembanding.

\begin{tabular}{|c|c|c|c|c|c|}
\hline & No. & Uraian & Objek Pembanding 1 & Objek Pembanding 2 & Objek Pembanding 3 \\
\hline \multirow{15}{*}{ 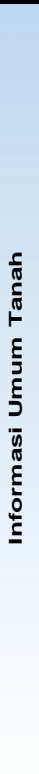 } & 1 & Jenis Real Properti & Tanah & Tanah & Tanah \\
\hline & \multirow[t]{5}{*}{2} & Alamat & JLSU & JDW & JM \\
\hline & & Desa/Kelurahan & Sentang & Selawan & Kisaran Naga \\
\hline & & Kecamatan & Kisaran Timur & Kisaran Timur & Kisaran Timur \\
\hline & & Kabupaten/Kota & Asahan & Asahan & Asahan \\
\hline & & Provinsi & Sumatera Utara & Sumatera Utara & Sumatera Utara \\
\hline & 3 & Koordinat (Latitude, Longitude) & $2.9,99.6$ & $2.9,99.6$ & $2.9,99.6$ \\
\hline & 4 & Luas Tanah $\left(\mathrm{m}^{2}\right)$ & 6.000 & 421 & 5.748 \\
\hline & 5 & Sumber Data & Lainnya/Visit & Lainnya/Visit & Lainnya/Visit \\
\hline & 6 & Telepon & 0000000 & 0000000 & 0000000 \\
\hline & 7 & Keterangan & 0000000 & 0000000 & 0000000 \\
\hline & 8 & Harga (Rp) & 6.000 .000 .000 & 350.000 .000 & 2.586 .600 .000 \\
\hline & 9 & Jenis Transaksi & Penawaran & Penawaran & Penawaran \\
\hline & 10 & Tanggal Transaksi & $15 / 01 / 2020$ & $18 / 11 / 2019$ & $10 / 09 / 2019$ \\
\hline & 11 & Hak Atas Tanah & Girik/Letter C/Belum Punya Hak & Hak Milik & Hak Milik \\
\hline
\end{tabular}

Sumber: Diolah dari Kertas Kerja Penilaian Pedekatan Data Pasar

Kondisi fisik properti yang diperoleh sebagai berikut :

Tabel 2 Kondisi Fisik Properti

\begin{tabular}{|c|l|l|l|l|l|}
\hline No. & Nama Objek & Bentuk Tanah & Posisi Tanah & Kontur Tanah & Aksesibilitas \\
\hline 1. & Objek Yang Dinilai & Persegi & Tengah & Datar & Jalan Kabupaten \\
\hline 2. & Objek Pembanding 1 & Lebih lebar di depan & Tengah & Datar & Jalan Nasional \\
\hline 3. & Objek Pembanding 2 & Lebih lebar di depan & Tengah & Datar & Jalan desa \\
\hline 4. & Objek Pembanding 3 & Lebih lebar di depan & Tengah & Datar & Jalan desa \\
\hline
\end{tabular}

Sumber: Diolah dari Kertas Kerja Penilaian Pedekatan Data Pasar

\section{Mengidentifikasi Sumber Data}

Berdasarkan observasi penulis sumber data yang diperoleh berasal dari data internal maupun data eksternal. Data internal berasal dari Sistem Informasi Direktorat Jenderal Pajak (SIDJP), Surat Pemberitahuan Objek Pajak (SPOP), bank pasar properti maupun data perpajakan lainnya. Data eksternal berasal dari survei lapangan, Badan Pusat Statistik (BPS) dan Olx.co.id.

\section{Analisis Data}

Setelah mengumpulkan dan memilih data yang akan digunakan maka tindak lanjutnya adalah menganalisis data. Analisis data terbagi menjadi dua analisis, yaitu analisis pasar properti dan analisis penggunaan tertinggi dan terbaik. Pada proses analisis data, hasil pengamatan penulis menemukan bahwa tim penilai belum menggunakan analisis pasar properti 
dan analisis penggunaan tertinggi dan terbaik (analisis highest and best use), namun sudah menggambarkannya pada kertas kerja penilaian pendekatan data pasar.

Menerapkan Pendekatan Dan Metode Penilaian

Pendekatan yang digunakan dalam melakukan penilaian properti harus disesuaikan dengan objek penilaian yang sedang dinilai. Seperti yang telah dijabarkan sebelumnya, objek penilaian yang sedang dinilai berupa tanah maka pendekatan penilaian yang paling relevan adalah pendekatan data pasar. Pendekatan data pasar menghasilkan indikasi nilai dengan cara membandingkan properti yang dinilai dengan properti yang sebanding dan sejenis dengan objek penilaian serta menggunakan proses perbandingan dan penyesuaian.

Berdasarkan observasi penulis, metode pendekatan data pasar yang digunakan oleh penilai adalah metode perbandingan data pasar. Metode perbandingan data pasar merupakan teknik perbandingan data yang sama atau sejenis dengan objek penilaian tetapi tidak identik untuk mendapatkan indikasi nilai. Ketidakidentikan yang terdapat dalam data pasar (data pembanding) dengan objek penilaian diperlukan adanya penyesuaian. Penyesuaian dilakukan untuk mengurangi perbedaan antara objek pembanding dengan objek penilaian. Penerapan data pasar dengan perbandingan data pasar dilakukan sebagai berikut : (1) Menggunakan data properti pembanding terkini. Menggunakan data properti pembanding terkini yang telah dikumpulkan sebelumnya pada. Properti pembanding yang telah dikumpulkan merupakan properti yang sebanding dan sejenis terhadap objek penilaian, berupa penawaran yang bersumber dari penjual dan agen properti. (2) Menyesuaikan jenis data atas properti pembanding. Penyesuaian jenis data atas properti pembanding untuk mendapatkan estimasi nilai pasar properti pembanding pada saat tanggal penilaian. (3) Membandingkan objek penilaian. Objek penilaian yang akan dinilai dibandingkan dengan properti pembanding yang telah dianalisis dengan menggunakan faktor-faktor penyesuaian. (4) Penyesuaian atas kondisi properti pembanding. Melakukan penyesuaian atas kondisi properti pembanding terhadap objek penilaian dengan menetapkan penyesuaian secara konsisten. Berdasarkan observasi penulis, penilai pajak penyesuaian atas beberapa aspek penting. Penyesuaian dilakukan atas jenis transaksi, waktu transaksi, hak atas tanah, lokasi dan fisik. Penyesuaian tersebut dipraktikkan pada tabel berikut.

Tabel 3 Data Sampel Menghitung Harga Rata-Rata Penawaran dan Jual Beli

\begin{tabular}{|c|c|l|r|r|}
\hline No & Nama Data & \multicolumn{1}{|c|}{ Lokasi } & Harga Penawaran (Rp) & Harga Jual Beli (Rp) \\
\hline 1 & & $\begin{array}{l}\text { Komplek Latsitarda, Kisaran Naga, Kisaran Timur, } \\
\text { Asahan }\end{array}$ & 1.000 .000 .000 & 1.000 .000 .000 \\
\cline { 2 - 5 } & & $\begin{array}{l}\text { Griya Kisaran Sari, Kisaran Naga, Kisaran Timur, } \\
\text { Asahan }\end{array}$ & 280.000 .000 & 280.000 .000 \\
\hline 3 & & Jalan Wirakarya, Teladan, Kisaran Timur, Asahan & 300.000 .000 & 300.000 .000 \\
\hline & \multicolumn{2}{|c|}{ Rata-rata } & 526.666 .667 & $\mathbf{5 2 6 . 6 6 6 . 6 6 7}$ \\
\hline
\end{tabular}

Sumber: Diolah dari Kertas Kerja Penilaian Pedekatan Data Pasar

Tabel 4 Penghitungan Penyesuaian Jenis Transaksi

\begin{tabular}{|c|c|c|c|}
\hline No. & Nama Objek Pembanding & $\begin{array}{c}\text { Jenis } \\
\text { Transaksi }\end{array}$ & $\begin{array}{c}\text { Penyesuaian } \\
\text { Jenis } \\
\text { Transaksi }\end{array}$ \\
\hline (1) & (2) & (3) & (4) \\
\hline 1. & Objek Pembanding 1 & Penawaran & $0,00 \%$ \\
\hline 2. & Objek Pembanding 2 & Penawaran & $0,00 \%$ \\
\hline 3. & Objek Pembanding 3 & $0,0 \%$ \\
\hline
\end{tabular}

Sumber: Diolah dari Kertas Kerja Penilaian Pedekatan Data Pasar 
Berdasarkan data dan wawancara dengan penulis, penyesuaian jenis transaksi dilakukan dengan memberikan perubahan sebesar 0\% secara keseluruhan (Tabel 5) karena objek pembanding setelah dilakukan penawaran kepada penjual tidak berkurang harganya antara harga penawaran dengan harga jual belinya. Dengan begitu, jenis transaksi antara objek pembanding dengan objek penilaian sudah sebanding.

Tabel 5 Rekapitulasi Penyesuian Waktu Transaksi dengan Teknik Penggunaan Data Inflasi

\begin{tabular}{|c|c|c|c|c|}
\hline No. & $\begin{array}{c}\text { Nama Objek } \\
\text { Pembanding }\end{array}$ & $\begin{array}{c}\text { Tanggal } \\
\text { Transaksi }\end{array}$ & $\begin{array}{c}\text { Selisih Jumlah } \\
\text { Bulan Dengan } \\
\text { Tanggal } \\
\text { Penilaian }\end{array}$ & $\begin{array}{c}\text { Penyesuaian } \\
\text { Waktu } \\
\text { Transaksi }\end{array}$ \\
\hline (1) & (2) & (3) & (4) & (5) =(b) $\times(4)$ \\
\hline 1. & Objek Pembanding 1 & $15 / 01 / 2020$ & 2,40 & $0,65 \%$ \\
\hline 2. & Objek Pembanding 2 & $18 / 11 / 2019$ & 4,30 & $1,16 \%$ \\
\hline 3. & Objek Pembanding 3 & $10 / 09 / 2019$ & 6,57 & $1,77 \%$ \\
\hline
\end{tabular}

Sumber: Diolah dari Kertas Kerja Penilaian Pedekatan Data Pasar

Penyesuaian waktu transaksi menggunakan teknik penggunaan data inflasi. Penyesuian diperoleh berdasarkan data inflasi regional tahunan sebesar 3,27\% dan inflasi regional rata-rata bulanan pada tahap pengumpulan data sebelumnya. Periode inflasi regional tahunan berada pada Februari 2019 s.d. Februari 2020. Penyesuaian jenis waktu transaksi dengan teknik data inflasi bertujuan untuk memperoleh persentase penyesuaian bulanan objek pembanding dengan objek penilaian.

Tabel 6 Jumlah Penyesuian Hak atas Tanah

\begin{tabular}{|ll|l|l|l|}
\hline Tarif Bea Perolehan Hak atas Tanah dan Bangunan (BPHTB) & $:$ & $5,00 \%$ & (a) & \\
\hline Persentase biaya pengurusan hak atas tanah dari harga transaksi & $:$ & $1,00 \%$ & (b) & \\
\hline Jumlah Penyesuaian hak atas tanah & $:$ & $6,00 \%$ & (c) & $=$ (a) + (b) \\
\hline
\end{tabular}

Sumber: Diolah dari Kertas Kerja Penilaian Pedekatan Data Pasar

Tabel 7 Rekapitulasi Penyesuaian Hak atas Tanah

\begin{tabular}{|c|c|l|r|}
\hline No. & $\begin{array}{c}\text { Nama Objek } \\
\text { Pembanding }\end{array}$ & Hak atas Tanah & $\begin{array}{c}\text { Penyesuaian Hak } \\
\text { atas Tanah }\end{array}$ \\
\hline (1) & (2) & \multicolumn{1}{|c|}{$(3)$} & (4) \\
\hline 1. & Objek Pembanding 1 & Girik/Letter C/Belum Punya Hak & $6,00 \%$ \\
\hline 2. & Objek Pembanding 2 & Hak Milik & $0,00 \%$ \\
\hline 3. & Objek Pembanding 3 & Hak Milik & $0,00 \%$ \\
\hline
\end{tabular}

Sumber: Diolah dari Kertas Kerja Penilaian Pedekatan Data Pasar

Penyesuian hak atas tanah dilakukan dengan menghitung semua biaya yang dikeluarkan untuk menyetarakan kepemilikan sebelumnya menjadi sertifikat kepemilikan (SHM) dengan disesuaikan kepada jenis hak yang dimiliki objek penilaian. Biaya yang dikeluarkan berdasarkan pada Tabel 7 terkait dengan biaya pengurusan hak atas tanah dari harga transaksi (1\%) dan BPHTB (5\%). Objek penilaian memiliki bukti kepemilikan berupa SHM. Berdasarkan keterangan pada Tabel 8, objek pembanding 1 hak atas yang dimiliki masih berbentuk girik sehingga diperlukan penyesuaian positif sebesar 6\% agar sebanding dengan objek penilaian.

Tahap selanjutnya adalah penyesuaian lokasi dan fisik. Berdasarkan observasi penulis, penyesuaian lokasi dan fisik ditentukan dengan menggunakan Multiple Regresion Analysis (MRA) dengan berdasarkan pada faktor lokasi atau fisik yang dominan mempengaruhi nilai tanah objek yang dinilai dan memberikan nilai tingkat kepentingan antar faktor lokasi dan fisik 
yang dominan tersebut. Perhitungan MRA terlampir dalam lampiran penulisan ini. Penyesuian lokasi dan fisik properti dapat dilihat pada tabel berikut.

Tabel 8 Rekapitulasi Penyesuaian Lokasi dan Fisik

\begin{tabular}{|c|c|l|r|}
\hline No. & $\begin{array}{c}\text { Nama Objek } \\
\text { Pembanding }\end{array}$ & Hak atas Tanah & \multicolumn{2}{|c|}{$\begin{array}{c}\text { Penyesuaian Hak } \\
\text { atas Tanah }\end{array}$} \\
\hline (1) & (2) & \multicolumn{1}{|c|}{ (3) } & \multicolumn{1}{|c|}{ (4) } \\
\hline 1. & Objek Pembanding 1 & Girik/Letter C/Belum Punya Hak & $6,00 \%$ \\
\hline 2. & Objek Pembanding 2 & Hak Milik & $0,00 \%$ \\
\hline 3. & Objek Pembanding 3 & Hak Milik & $0,00 \%$ \\
\hline
\end{tabular}

Sumber: Diolah dari Kertas Kerja Penilaian Pedekatan Data Pasar

Penyesuaian lokasi dan fisik dilakukan pada seluruh objek pembanding dan dapat dilihat pada Tabel 9. Penyesuaian lokasi dan fisik pada Objek pembanding 1 sebesar 2,86\%, objek pembanding 2 sebesar 36,24\% dan objek pembanding 3 sebesar 36,24\%. Dengan dilakukannya penyesuaian maka objek pembanding sudah dikatakan sebanding dengan objek penilaian dari sisi lokasi dan fisik.

\section{Melakukan Rekonsiliasi Nilai}

Rekonsiliasi merupakan tahapan lanjutan setelah menerapkan pendekatan dan metode pendekatan yang digunakan yaitu pendekatan data pasar dan perbandingan data pasar. Proses rekonsiliasi umumnya digunakan untuk melakukan pencocokan pendekatan yang digunakan dalam penilaian. Namun pada penilaian yang penulis bahas, objek penilaian yang dinilai berupa tanah, sehingga pendekatan penilaian yang dapat digunakan hanya pendekatan data pasar. Dengan begitu, proses rekonsiliasi pada penilaian ini terbatas kepada penyesuaian yang telah dilakukan terhadap data pembanding untuk mengetahui persentase penyesuaian dalam menentukan indikasi nilai pada objek penilaian. Rekonsiliasi penyesuaian dapat dilihat sebagai berikut.

Tabel 9 Rekonsiliasi Penyesuaian Objek Pembanding

\begin{tabular}{|c|c|c|c|c|c|c|c|c|}
\hline \multirow[b]{2}{*}{ No. } & \multirow[b]{2}{*}{$\begin{array}{l}\text { Nama Objek } \\
\text { Pembanding }\end{array}$} & \multicolumn{4}{|c|}{$\%$ Penyesuaian } & \multirow{2}{*}{\begin{tabular}{|c|} 
Jumlah Nilai \\
Absolut dari \\
Persentase \\
Masing-masing \\
Hasil \\
Penghitungan \\
Penyesuaian (\%)
\end{tabular}} & \multirow{2}{*}{$\begin{array}{c}\text { Indeks } \\
\text { Kesebandingan } \\
\text { Objek } \\
\text { Pembanding } \\
\text { Terhadap Objek } \\
\text { Yang Dinilai }\end{array}$} & \multirow[b]{2}{*}{$\begin{array}{l}\text { Bobot untuk } \\
\text { Rekonsiliasi } \\
\text { Nilai (\%) }\end{array}$} \\
\hline & & $\begin{array}{c}\text { Jenis } \\
\text { Transaksi }\end{array}$ & $\begin{array}{c}\text { Waktu } \\
\text { Transaksi }\end{array}$ & $\begin{array}{c}\text { Hak Atas } \\
\text { Tanah }\end{array}$ & $\begin{array}{c}\text { Lokasi } \\
\text { dan Fisik }\end{array}$ & & & \\
\hline (1) & (2) & (3) & (4) & (5) & (6) & \begin{tabular}{|c|} 
(7) $=\sum$ nilai \\
absolut (3), (4), \\
(5), (6) \\
\end{tabular} & $(8)=1-(7)$ & $(9)=(8) / \Sigma(8)$ \\
\hline 1. & Objek Pembanding 1 & $0,00 \%$ & $0,65 \%$ & $6,00 \%$ & $2,86 \%$ & $9,51 \%$ & 0,90 & $42,07 \%$ \\
\hline 2. & Objek Pembanding 2 & $0,00 \%$ & $1,16 \%$ & $0,00 \%$ & $36,24 \%$ & $37,40 \%$ & 0,63 & $29,11 \%$ \\
\hline 3. & Objek Pembanding 3 & $0,00 \%$ & $1,77 \%$ & $0,00 \%$ & $36,24 \%$ & $38,01 \%$ & 0,62 & $28,82 \%$ \\
\hline
\end{tabular}

Sumber: Diolah dari Kertas Kerja Penilaian Pedekatan Data Pasar

Rekonsiliasi penyesuian objek pembanding menghasilkan bobot yang berbeda pada setiap objek pembanding. Bobot objek pembanding 1 sebesar 42,07\%, objek pembanding 2 sebesar 29,11\% dan objek pembanding 3 sebesar 28,82\%. Bobot rekonsiliasi berpengaruh kepada indikasi nilai dari objek penilaian. Berdasarkan analisis terhadap objek penilaian dan objek pembanding yang diperoleh, maka nilai pasar objek penilaian yang menjadi objek pajak adalah sebagai berikut. 


\begin{tabular}{|c|l|r|r|c|}
\hline No. & Objek Penilaian & Luas (m2) & Nilai/m2 & Nilai \\
\hline 1 & Tanah & 110 & 975.019 & 107.252 .090 \\
\hline
\end{tabular}

Tabel 10 Nilai Pasar Objek Penilaian

Sumber: Diolah dari Laporan Penilaian Properti Kriteria I

Kesimpulan nilai pasar untuk tahun 2020 atas tanah objek penilaian dengan mempertimbangkan berbagai faktor yang mempengaruhi nilai, nilai pasar ditetapkan sebesar Rp107.252.090 (Seratus tujuh juta dua ratus lima puluh dua ribu). Tahap selanjutnya setelah diketahui kesimpulan nilai maka perlu dilakukan perbandingan nilai atas permohonan penelitian bukti pemenuhan kewajiban penyetoran pajak penghasilan atas penghasilan dari pengalihan hak atas tanah dan/atau bangunan yang disampaikan wajib pajak. Berdasarkan data yang disampaikan wajib pajak dan hasil penilaian yang dilakukan penilai pajak, dapat ditampilkan sebagai berikut.

Tabel 11 Data Perbandingan Nilai antara Wajib Pajak dengan Penilai Pajak

\begin{tabular}{|r|r|r|r|}
\hline No. & Nilai Wajib Pajak & Nilai Hasil Penilaian & \multicolumn{1}{c|}{ Penambahan } \\
\hline 1 & $80.000 .000,00$ & $107.252 .090,00$ & $27.252 .090,00$ \\
\hline
\end{tabular}

Sumber: Diolah dari Laporan Penilaian Properti Kriteria I

Berdasarkan observasi penulis, penambahan nilai atas transaksi yang dilakukan sebesar Rp27.252.090 dengan nilai yang diakui wajib pajak dapat menambah penghasilan bagi wajib pajak yang belum dikenakan PPh Pasal 4 Ayat (2) atas pengalihan hak atas tanah dan/atau bangunan. Dengan begitu, hasil penilaian yang dilakukan oleh penilai dapat ditindaklanjuti dan dijadikan bahan pertimbangan bagi AR untuk menghitung ulang pajak terutang yang dikenakan atas wajib pajak tersebut. Sebab, dengan adanya penambahan nilai transaksi dapat dikatakan bahwa adanya ketidakwajaran nilai transaksi pengalihan hak atas tanah dan/atau bangunan yang dilakukan dan menimbulkan adanya potensi kekurangan PPh yang seharusnya terutang oleh wajib pajak.

\section{Membuat Laporan Penilaian}

Tahap akhir dari proses penilaian pengalihan hak atas tanah dan/atau bangunan di KPP Pratama Kisaran adalah pelaporan penilaian yang disajikan dalam bentuk laporan penilaian secara utuh sebagai bentuk pertanggungjawaban atas kegiatan penilaian dan kesimpulan nilai yang dihasilkan. Pertanggungjawaban disampaikan kepada pemberi tugas dalam hal ini merupakan kepala kantor. Laporan penilaian digunakan oleh banyak kalangan dan tidak hanya kepada pemangku kepentingan internal DJP seperti penilai pajak maupun fiskus. Namun, laporan penilaian dapat digunakan dan dipahami oleh pihak - pihak lain yang memiliki kepentingan diluar dari bidang penilaian, seperti wajib pajak maupun hakim pajak. Maka diperlukan informasi yang lengkap, jelas dan mudah dipahami. Laporan penilaian dan kertas kerja penilaian yang disampaikan harus sudah ditandatangani oleh penilai pajak.

\section{PENUTUP}

\section{Simpulan}

Pelaksanaan penilaian properti dalam rangka menentukan kewajaran nilai transaksi pengalihan hak atas tanah dan/atau bangunan di KPP Pratama Kisaran pada dasarnya sudah mengikuti Standar Operasional Prosedur (SOP) sesuai dengan peraturan yang berlaku,

\section{Saran}

Pada penelitian kualitatif ini kami mendapati beberapa tantangan dan hambatan dalam melaksanakan penilaian properti dalam rangka menentukan kewajaran nilai transaksi pengalihan hak atas tanah dan/atau bangunan di KPP Pratama Kisaran, sehingga diharapkan : 
(1) Unit kerja/pejabat yang berkompeten dapat meminimalisir hambatan-hambatan yang dialami penilai pajak dalam melakukan penilaian, antara lain melakukan kerjasama dengan pemangku kepentingan seperti dengan BPS/pemilik data lain untuk pembentukan database yang mengkaomodir data-data pendukung penilaian, antara laian : data pembanding yang sebanding dan sejenis, data terkait komponen pembentuk bangunan, pembaruan data inflasi, data harga material bangunan. (2) Pembangunan/pengelolaan jalan menuju Objek Penilaian. Di wilayah Kabupaten Asahan, Kabupaten Batubara dan Kota Madya Tanjung Balai yang menjadi wilayah kerja KPP Pratama Kisaran, karena memiliki aksesibilitas yang masih jauh dari fasilitas perkotaan khususnya dengan jalan beraspal secara keseluruhan. Aksesibilitas yang kurang memadai menyulitkan mengakses lokasi objek penilaian.

\section{DAFTAR PUSTAKA}

Undang-Undang Republik Indonesia Nomor 36 Tahun 2008 tentang Pajak Penghasilan

Peraturan Pemerintah Republik Indonesia Nomor 34 Tahun 2016 tentang Pajak Penghasilan atas Penghasilan dari Pengalihan Hak atas Tanah dan/atau Bangunan, dan Perjanjian Pengikatan Jual Beli atas Tanah dan/atau Bangunan Beserta Perubahannya

Peraturan Direktur Jenderal Pajak Nomor PER-18/PJ/2017 tentang Tata Cara Penelitian Bukti Pemenuhan Kewajiban Penyetoran Pajak Penghasilan atas Penghasilan dari Pengalihan Hak atas Tanah dan/atau Bangunan, dan Perjanjian Pengikatan Jual Beli atas Tanah dan/atau Bangunan Beserta Perubahannya

Peraturan Direktur Jenderal Pajak Nomor PER-21/PJ/2019 tentang Perubahan Kedua atas Peraturan Direktur Jenderal Pajak Nomor PER-18/PJ/2017 tentang Tata Cara Penelitian Bukti Pemenuhan Kewajiban Penyetoran Pajak Penghasilan atas Penghasilan dari Pengalihan Hak atas Tanah dan/atau Bangunan, dan Perjanjian Pengikatan Jual Beli atas Tanah dan/atau Bangunan Beserta Perubahannya

Subekti. (2001). Pokok-Pokok Hukum Perdata. Jakarta : Intermasa

Surat Edaran Dirjen Pajak Nomor SE-54/PJ/2016 tentang Petunjuk Teknis Penilaian Properti, Penilaian Bisnis, dan Penilaian Aset Tak Berwujud untuk Tujuan Perpajakan

Surat Edaran Dirjen Pajak Nomor SE-05/PJ/2020 tentang Prosedur Pelaksanaan Penilaian untuk Tujuan Perpajakan

Surat Edaran Dirjen Pajak Nomor SE-28/PJ/2020 tentang Petunjuk Pelaksanaan Penelitian Bukti Pemenuhan Kewajiban Penyetoran Pajak Penghasilan atas Penghasilan dari Pengalihan Hak atas Tanah dan/atau Bangunan, dan/atau Perubahan Perjanjian Pengikatan Jual Beli atas Tanah dan/atau Bangunan

KPP Pratama Kisaran. (2020). Laporan Penilaian Properti Kriteria I. Asahan. 